\title{
A Ukrainian line on science and education?
}

SCIENTIFIC research and education in the Ukrainian SSR is failing to meet the demands of the "scientific and technical revolution", according to Volodymyr V. Shcherbyts'kyy, first Secretary of the Central Committee of the Communist Party of Ukraine.

Addressing a meeting of university and college lecturers, Shcherbyts'kyy called for a "comprehensive attitude" to research, in terms which could be taken as a criticism of current Soviet policy.

Of recent years, policy has stressed the development of close contacts between academic institutions and local industry, with the scientists undertaking $\mathrm{R} \& \mathrm{D}$ on a contract basis as and when required. This, in Shcherbyts'kyy's opinion, is simply inadequate.

"Contracts between higher educational institutions and production are still essentially reduced to the conclusion of economic agreements with the neighbouring enterprises, and these agreements are frequently aimed at accomplishing particular, minor, tasks", he said. "A solution at the level of the entire branch practically never occurs".

What precisely Shcherbyts'kyy had in mind is not entirely clear Presumably he would replace the present ad hoc trouble-shooting with a more structured programme of problemorientated R \& D, somewhat on the Polish model. Such a system, he im- plied, would need to be organised on the regional level by the Ukrainian republic.

At present, he said, the Ukrainian Ministry of Education "has no joint plans with any [other] Ukrainian Ministry", although it is carrying out "several comprehensive plans" with the All-Union Ministry of the Chemical Industry. This lack of contact with production at the republic level, said Shcherbyts'kyy, is apparently why only about $20 \%$ of the inventions patented by scientists at higher educational institutions in Ukraine ever get applied in industrial production.

The relationship between the economies of the Union Republics and the central planning authorities is a complex one, and the relevant paragraphs of the new Soviet constitutions do little to clarify the matter.

Long ago in the 1950s Krushchev tried to over-ride the republic boundaries with a system of arbitrary economic planning regions. Although this set-up has been abandoned, at least as far as education and academic life is concerned, there has been a constant trend towards centralisation in the last two decades.

Recently, scientific publication in languages other than Russian has virtually ceased, and several promising lines of research in individual republics disappeared into main-stream anonymity. The distinctive Ukrainian school of cybernetics of the early 1960 s was probably the most notable such loss. Young graduates on leaving university are drafted wherever the economy requires-generally to the new towns of Siberia.

To date Shcherbyts'kyy has shown no signs of Ukrainian national sentiment-indeed, he was appointed in 1972 to replace Shelest, who fell from power precisely for his overlyUkrainian attitude.

So First Secretary Shcherbyts'kyy's advocacy of strengthening academicproduction contacts at a republic level seems essentially a pragmatic response to a pressing economic need, not a criticism of Soviet "nationalities policy", which to date he has resolutely supported.

On educational policy, however, he does seem prepared to make a cautious criticism. After noting "frequent cases of formalism", "unproductive use of time" and "a peculiar percentage mainia" in assessing the knowledge of students", he went on to the "participation of pupils and students in construction detachments and in agricultural operations"- officially viewed as a major factor in communist education.

Although paying official tribute to the "importance" of such activities, he nevertheless found it "necessary to emphasise that studies must be the first objective to which the student must apply his efforts". Vera Rich

\section{Soviet soil erosion laboratory defends its economic record}

Moscow University's laboratory of soil erosion and river bed processes is already saving the Soviet economy some 10 million roubles per annum. So said its director, Dr Roman S. Chalov, interviewed on Moscow radio last month on the tenth anniversary of the opening of the laboratory.

Appraisal of $R$ \& D in terms of payoff and cost-effectiveness is a regular Soviet practice-although perhaps more common among policy-makers than scientists.

Dr Chalov's laboratory, however, is in a somewhat sensitive position. Last December, the Party Central Committee and the USSR Council of Ministers adopted a resolution "On additional measures to strengthen nature conservation and to improve the use of natural resource, and among the sectors singled out for special criticism, the resolution mentions soil erosion, which the planners note "is doing considerable harm to the national economy".
Dr Chalov's laboratory, being the only one in the Soviet Union specifically devoted to erosion problems, can hardly have taken this observation lightly. Chalov's anniversary interview accordingly became an apologia for the work of the laboratory. The 10 million per annum, he implied, was merely an earnest of what the laboratory hopes to do.

At present the team are largely concerned with feasibility studies. In the North Caucausus agricultural area, a study has been made of the economic efficiency of different anti-erosion measures, giving special attention to the "accelerated erosion" produced by agriculture. A further field study will be undertaken this year in the nonblack soil zone of the Russian SFSR. Development of this region of relatively poor agricultural land has a special place in the current Five Year Plan. Here the team will study gully erosion-- the destruction of the land by flash floods and torrents.
This extensive programme of antierosion work, actual and potential, has one rather surprising omission. It is entirely water-related, and has no con cern with wind-erosion and desertification. This is the more surprising since Khrushchev's policy of horizonto-horizon cultivation of the virgin lands has created a number of incipient dust-bowls.

Desert erosion, is the concern not of Moscow University, but of Leningrad. A major expedition from Leningard University and the Main Geophysical Laboratory last summer made a detailed study of the formation and growth of dust-storms in Soviet Central Asia.

According to the teamleader, Dr Kiril Kondrat'ev, the main subject of study was the "anti-hothouse" effect, which occurs during dust-storms which extend to high altitudes, cooling the Earth's surface by reflecting solar radiation.

Vera Rich 